\title{
André Martineau: Some Memories
}

\section{Christer Oscar Kiselman ${ }^{1}$ (D)}

Received: 11 July 2020 / Accepted: 3 August 2020 / Published online: 14 September 2020

(C) The Author(s) 2020

\section{Abstract}

This essay presents memories of André Martineau (1930-1972).

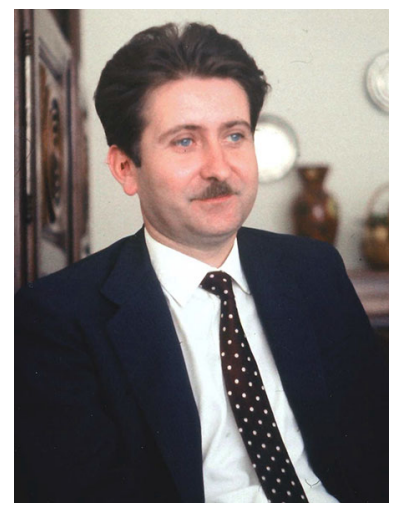

André Martineau was a great mathematician and a great human being. I knew him, having spent the academic year 1967-1968 with him in Nice. The photo shows him in his home in Nice on 1968 September 27. (Photo taken by author.)

Dedicated to the memory of André Martineau at the occasion of the ninetieth anniversary of his birth.

Communicated by Irene Sabadini.

This article is part of the topical collection "Higher Dimensional Geometric Function Theory and Hypercomplex Analysis" edited by Irene Sabadini, Michael Shapiro and Daniele Struppa.

$\bowtie$ Christer Oscar Kiselman

kiselman@it.uu.se; christer@kiselman.eu

https://www.cb.uu.se/ Kiselman

1 Department of Information Technology, Uppsala University, P. O. Box 337, 75105 Uppsala, Sweden 


\section{How I Was Invited to Work with Martineau}

My first contact with Martineau dates back to 1966: I had sent him my first papers, of which the second was about analytic functionals which possess a unique convex or holomorphically convex support. He answered me with a card; I quote:

They are very interesting; in particular I had not dreamed about statements of the type Theorem 3.1, page 314. ${ }^{1}$

(Martineau 1966 March 22)

He continues: "But I think that you can improve your statements," and he presents his ideas on this problem. ${ }^{2}$

He was at the time in Montpellier, me in Princeton.

We became engaged in a correspondence on analytic functionals. For example, on 1966 July 11, I asked him whether the intersection of all convex supports of a nonzero analytic functional is always nonempty. He answered by a card of 1966 August 31 and mailed in the department of Lozère: "I had asked myself your question and I had thought that I answered it in the negative, but I am currently incapable to retrieve my reasons for this. I might have been mistaken. ${ }^{3}$ Soon I will come back to Montpellier and I will see if I have some notes on this topic." On October 18 he continues by reporting that he had found his notes and drafts from Rio de Janeiro, and adding that he had abandoned the question, however without really knowing why.

In fact, he was right in giving a negative answer, but this was proved only much later: in 1993 Sergej V. Znamenskij constructed a nonzero functional which possesses three convex supports with empty intersection.

A part of his letter of October 18 is devoted to praising the region: "From the point of view of tourism, this region is inexhaustible. The Mediterranean landscapes, being very sober and stripped-off under the southern light, do not make you tired. And the historical and even prehistorical treasures are innumerable. You have memories from -2500 to +1966 ."

In this letter Martineau invites me to Montpellier. The idea had been transmitted earlier by Gunter Bengel, whom I had met in Moscow in July. However, on 1967 January 16 he writes to inform me about a new development: "Dieudonné has asked me to come to Nice, and I should answer before the first of February." Already on January 23 he writes again: "It is decided. I am going to Nice and you will follow me there. Indeed, the section at Nice has agreed to take you as Maître de conférences associé [visiting professor]." Jean Dieudonné was Dean of the Faculty of Science and was most efficient in bringing several very good mathematicians to Nice. He was "un Doyen très dynamique" according to Martineau (letter of 1967 February 25). Nobody could contradict this assertion ... And he describes the environment in Nice by continuing: "We have at Nice Douady, Houzel, Krée, Zerner, Dieudonné, Grisvard

\footnotetext{
1 Translations of quotes in French like this one have been done by the author.

2 I had stated an hypothesis in Theorem 3.1 of my article 65-2 which was unnecessarily strong. Later he published the article (1967), where he uses a weaker hypothesis in the case of a convex support. However, he does not treat the case of a holomorphically convex support (Theorem 3.2 in 65-2), which thus remains to be improved-if possible.

3 This remark has given birth to "Martineau's Principle," which warns us that if one cannot reconstruct a proof once formulated, it is because it was in error.
} 
(October) and me. They are all young, except Dieudonné and (possibly) me. And some, like Douady, of an exceptional class."

I arrived to Nice on one of the first days of October 1967 with my wife Astrid and our two sons, of which the older, Dan, was four years old, and the younger, Ola, only four months. ${ }^{4}$ After a few days, on October 10 , we could rent an apartment in a beautiful house in Cimiez, not far from Parc de Valrose, where mathematics was located.

\section{In Nice Around Martineau}

Since 1954, André Martineau was married to Christine, née Génieys. She was a student at the École normale supérieure of Sèvres, where she had met André, himself a student at the École normale supérieure of Ulm street. At the time I am referring to, the years 1967-1968, she taught at the Faculty of Letters in Nice, being a specialist in the history of the Middle Ages and the renaissance. A few years later, she presented her doctoral thesis at the University of Montpellier (1974). For some of her publications, see the bibliography, and, for her work on the Middle Ages, also the web site ARLIMA at the address https://www.arlima.net/. For her book (1975) she received a prize, the Prix de la Fondation la Fons-Mélicocq in 1976; for her book (1979) another prize in the year 1980: the Prix Feydeau de Brou de l'Académie Française. In 1992, she organized a conference at the University of Nice Sophia Antipolis, the proceedings of which were published (1996).

The couple had four children: Anne, ${ }^{5} \mathrm{Jean}^{6}{ }^{\text {Pierre }}{ }^{7}$ and Jacques. ${ }^{8}$

Around Martineau there were the mathematicians already mentioned: Jean Dieudonné (1906-1992), Adrien Douady (1935-2006), Pierre Grisvard (1940-1994), Christian Houzel, Paul Krée, Martin Zerner (1932-2017); all of them were to become very important for me. Chin-Cheng Chou, Jacques Frisch and André Hirschowitz were there also, and, as visitors for the academic year 1967-1968, Gunter Bengel, Mitsuo Morimoto and Akira Morimoto (a married couple), and me. For a shorter period we were joined by Pierre Schapira. Towards the end of the year it was decided to employ a young assistant for the next year: Henri Skoda. He arrived only when I had left, but I have met him on many occasions later.

The working conditions were very good. Also the climat in Nice suited me perfectly. Martineau's presence was a constant inspiration. During the year I wrote five articles

\footnotetext{
4 In spite of this change, I could become acquainted with the city of Montpellier, Martineau's former university. I was invited there by Charles Roumieu to give a talk on 1968 May 13. It could not take place because of extensive demonstrations in Paris on the same day. Thirty years later, in August of 1998, I spent a whole week in Montpellier.

5 Born in 1955, teacher and researcher at the University Jean Monnet in Saint-Étienne.

6 Born in 1960, musician.

7 Born in 1961, a former student at l'École Polytechnique, Deputy Director and researcher at the Research Institute for Oncology at the University of Montpellier (Institut de Recherche en Cancérologie de Montpellier, IRCM).

8 Born in 1963, a former student of the National Normal School (ENS) at Ulm street, teacher and researcher at the University of Paris in Nanterre, film director and screenplay writer.
} 
(68-1, 68-2, 68-3, 68-4 and 69-1), of which three were in French. André Hirschowitz corrected my errors in French (towards the end of the year they were fewer than in the beginning). To prepare my lectures I used a tape recorder in order to listen to my own pronunciation. In the beginning it was not so easy to lecture, since my French from school was not sufficient for conversations.

\section{Lineal Convexity}

Martineau lectured on lineally convex sets; I became interested, and later, in 1978, wrote a paper on them (78-2). As I was of the opinion that the results on these sets were spread out in an unsatisfactory manner, and not always had optimal proofs, I recommended my $\mathrm{PhD}$ student Mikael Passare (Pettersson at the time) to write a survey article. On the one hand, this was clearly an excellent idea, since it turned out that he found a lot of results together with his colleagues Mats Andersson and Ragnar Sigurdsson, but on the other hand it was perhaps not such a good thing, since the survey article did not stop growing and the paper remained unfinished during several years, although partial preprints were circulated and even quoted in articles and books. All in all, it is thanks to Martineau that I have this interest, and if the three mathematicians Andersson, Passare and Sigurdsson took such a long time to finish their study, it is not my fault, at least not directly, since I had just passed the torch. However, I returned myself to the subject in $1995 \ldots$ and it is not finished.

\section{The Indicator Theorem}

As already mentioned, the reason behind the invitation to Nice was our common interest in analytic functionals. But it is rather our work on the existence of entire functions of prescribed growth which has left some traces.

Indeed, we have followed the same route, although in opposite directions. I started by proving the existence of an entire function of exponential type with prescribed indicator using the $L^{2}$ estimates for the Cauchy-Riemann operator $\bar{\partial}$. But I could not finish in the general case, when the given plurisubharmonic function is arbitrary: I was obliged to suppose that it was Lipschitz (in my letter of 1966 July 11, I remarked that the same proof with the $L^{2}$ methods was valid also in the more general case of Hölder continuity). It was for this reason that I was searching for another way, viz. that of the projective Borel transformation.

On the side of the Borel transforms I could perform the necessary approximations, which enabled me to obtain the general resultat, i.e., that every plurisubharmonic function which is positively homogeneous of order one (even discontinuous) is an indicator. It is this proof that I published in Acta Mathematica (manuscript received 1966 May 31). I lectured on this result in Princeton on 1965 December 06. Martineau started instead with this method, which he describes in Lelong's seminar of 1966 June 06; the written version is from June 1967. Then he made the proof with the $L^{2}$ methods, published in Inventiones (manuscripts received 1966 July 10 and 1967 February 10). So he could make an approximation in the case when the given function 
is no longer supposed to be continuous or Lipschitz. In addition, this proof holds for any finite order, while the proof with the Borel transformation necessitates order one. So we had worked independently and proved more or less the same result, even though Martineau had proved a more general theorem (arbitrary finite order). Before us, in 1965, Pierre Lelong (1912-2011) had proved the theorem assuming that the given plurisubharmonic function is complex homogeneous, thus under a more restrictive hypothesis, and in a situation where the Borel transformation works easily.

\section{The Philosophy of Mathematics}

André Martineau had ideas on the philosophy of mathematics and scientific methods in general, even though, as far as I am aware, he has not written anything on this subject.

The classical mathematical method, that is, the axiomatic method, is too limited, he said once after having taught, still wearing his white medical robe and his hands not yet free from chalk dust. It is necessary to use broader, more intuitive methods. In the future, mathematicians will do so. He looked at me with his very bright blue eyes. I did not understand much. But I think that he was right. The axiomatic method is indeed narrow. Mathematicians do not find their results in this way, this is more or less evident by introspection ... if that is an argument. Applied mathematicians often verify their results by calculations, which give a kind of quasi-truth, or perhaps better than that. (Evidently I cannot be sure that this was what he thought.)

\section{How to Classify the Books in a Mathematical Library?}

On a Saturday in the fall of 1967, October 28, at 2:30 p.m., folks at the math department were summoned to a meeting to reclassify the books in the department's library. Several professors were there-Dieudonné leading the crowd. He attribuated to each book its signature, following a recently established system, which was-I think-a slight modification of the system already in use. ${ }^{9}$ Dieudonné, indefatigable, directed the whole process, and the others carried the books here and there at maximum speed. However, Martineau was not there. In a most touching letter dated 2014 January 12, Christine Martineau gave me a completely convincing reason: her husband had promised to go on an excursion with her on the very same Saturday.

Before the meeting, Martineau had revealed to me the system he preferred: to classify the books according to the system of the Mathematical Reviews. Thus one would not have to invent a system on one's own. And if the system of the Math Reviews were to change in the future, one could make the same change also in the library, that would not be a great problem. On the Monday following the meeting, he was a bit

\footnotetext{
9 Indeed, a decision by the mathematical section, made on 1967 October 28 (in the absence of Martineau) indicated that an "analytical catalogue" of the library was to be established. "M. Dieudonné (a decision taken in his absence) shall give the principles for a reclassification of the books according to a new system." And it was Dieudonné who was the author of the greatest part of this new classification, Douady, Frisch, Grisvard, Houzel, Krée and Zerner having contributed to some chapters.
} 
disappointed that his advice had not been followed. But Jacques Frisch remarked that he had no reason to complain: he was not present, he had been spared, and the work had been done without any effort on his part. This is therefore the simplest method of all: not to do anything at all.

This idea stayed with me, and when our department in Uppsala was going to move ten years later, in 1978, I proposed that the library should be classified according to the system of the Math Reviews. Nobody listened to me, and the old system remained as it had been for a long time - that it is not sufficient to come up with a good idea had now been proved twice. But fourteen years later, in 1992, we were going to move again, and this time I was a bit more stubborn: I wrote a little memorandum that I distributed more or less everywhere and with precise indications - and this time the librarians followed my proposal. After the habitual muttering, everybody was content, and I hear even today expressions of satisfaction, especially from visitors, who of course know the Math Reviews. I have noticed during visits that our library is not the only one to use this system, but I think that in 1967, and even in 1978, it was a rather original idea. It is with pleasure that I tell visitors that the Beurling library in Uppsala (nowadays called the Ångström library) is classified according to an idea of André Martineau from 1967.

\section{Jean Dieudonné}

On 1967 November 30, at 5:30 p.m., Jean Dieudonné gave a public lecture in the center of Nice. This was an effort in the direction of making science better known; I do not remember whether there was a whole series of lectures or whether the event was unique. My wife Astrid, who is not a mathematician, was also there. Dieudonné gave a rather long presentation and presented several chapters of the mathematical sciences. I remember in particular that he, with strong emphasis, gave us his opinion on the responsibility of scientists concerning the use of their results: if parents give matches to their children, those who made these matches (the scientists) were not in the least responsible ... one could think about nuclear bombs or ...

We can even now follow his ideas: they are expressed in the introduction to his book (1987:9-13). Before coming to Nice I had read his book (1967), of which a first edition had appeared in 1960.

\section{It Is Sad ...}

André Martineau was born on 1930 May 14 and died on 1972 May 04. It is indeed sad that this great personality disappeared from us so early.

Laurent Schwartz (1977:7) writes about him that, as a child, "Above all, he raised questions and was never satisfied with answers that were not complete." Later Schwartz writes (1997:291): "He was intelligent and subtle, most original, of a mild and genereous temperament." I am in complete agreement with this characterization.

I remember even today things he said in the corridor near the mail boxes where the mathematicians often met. Once, passing us in the corridor, he uttered: "Je suis 
contre !" (I am against that!), without having the slightest idea of what we were talking about.

He had an extraordinary humor. His irony was of the mildest kind possible, never malevolent but always very much to the point.

Briefly, he was a person who has influenced me a lot: I have learnt enormously from him in the field of mathematics, but equally much from his vision of life.

\section{In Conclusion}

The book by Mats Andersson, Mikael Passare and Ragnar Sigurdsson came out in 2004, when 36 years had passed since 1968. We have seen the development of the subjects treated in this book during the last sixteen years; a new edition would perhaps be desirable. The death of one of the authors now makes this less probable: Mikael Passare died in Oman on 2011 September 15 at the age of 52.

My article "Weak lineal convexity" was published in March 2016 (number 16-1 in my web site) ... it will perhaps be my next to last text on lineal convexity. In 2019 my article 19-1 came out.

Acknowledgements I thank most sincerely Christine Martineau-Génieys as well as her daughter Anne Martineau and her son Pierre Martineau for information of utmost importance that they shared with me. Lawrence Gruman, André Hirschowitz and Nicolas Pielawski sent me comments and corrections, and I am very grateful for this.

Funding Open access funding provided by Uppsala University.

Data Availability Statement There are no data related to this essay.

Open Access This article is licensed under a Creative Commons Attribution 4.0 International License, which permits use, sharing, adaptation, distribution and reproduction in any medium or format, as long as you give appropriate credit to the original author(s) and the source, provide a link to the Creative Commons licence, and indicate if changes were made. The images or other third party material in this article are included in the article's Creative Commons licence, unless indicated otherwise in a credit line to the material. If material is not included in the article's Creative Commons licence and your intended use is not permitted by statutory regulation or exceeds the permitted use, you will need to obtain permission directly from the copyright holder. To view a copy of this licence, visit http://creativecommons.org/licenses/by/4.0/.

\section{References}

Andersson, Mats; Passare, Mikael; Sigurdsson, Ragnar. 2004. Complex Convexity and Analytic Functionals, xii +160 pp. Progress in Mathematics, 225. Basel: Birkhäuser Verlag.

Dieudonné, J[ean]. 1967. Fondements de l'analyse moderne, XVIII + 375 pp. Translated from English by D[enise] Huet. Paris: Gauthier-Villars.

Dieudonné, Jean. 1987. Pour l'honneur de l'esprit humain. Les mathématiques aujourd'hui, 298 pp. Paris: Hachette.

Kiselman, C. O. 65-2. On unique supports of analytic functionals. Arkiv för matematik 6 (1967), 307-318 (1965, 1966). 
Kiselman, Christer O. 68-1. Functionals on the space of solutions to a differential equation with constant coefficients. The Fourier and Borel transformations. Mathematica Scandinavica 23 (1968), 27-53.

Kiselman, Christer O. 68-2. Existence of entire functions of one variable with prescribed indicator. Arkiv för matematik 7 (1969), 505-508 (1968).

Kiselman, Christer O. 68-3. Compacts d'unicité pour les fonctionnelles analytiques en une variable. Comptes Rendus de l'Académie des Sciences (Paris), Série A, 266 (1968), 661-663.

Kiselman, Christer O. 68-4. Supports des fonctionnelles sur un espace de solutions d'une équation aux dérivées partielles à coefficients constants. In: Séminaire Pierre Lelong (Analyse) Année 1967-68, pp. 118-126. Lecture Notes in Mathematics 71. Springer-Verlag, 1968.

Kiselman, Christer O. 69-1. Prolongement des solutions d'une équation aux dérivées partielles à coefficients constants. Bulletin de la Société mathématique de France 97 (1969), 329-356.

Kiselman, Christer O. 16-1. Weak lineal convexity. In: Białas-Cież, Leokadia; Kosek, Marta, Eds., Constructive Approximation of Functions. Banach Center Publications, volume 107, pp. 159-174. Warsaw: Polish Academy of Sciences (published in March 2016).

Kiselman, Christer Oscar. 19-1. Generalized convexity: The case of lineally convex Hartogs domains. Annales Polonici Mathematici 123 (2019), 319-344.

Martineau, André. 1967. Unicité du support d'une fonctionnelle analytique: Un théorème de C. O. Kiselman. Bull. Sci. Math. (2) 91, 131-141. Also in (CEuvres de André Martineau 1977:335-345).

Martineau-Génieys, Christine. 1972. Les Lunettes des princes de Jean Meschinot. Publications romanes et françaises, 121. Geneva: Droz.

Martineau-Génieys, Christine. 1975, 1979. Guillaume Briçonnet et Marguerite d'Angoulême. Correspondence 1521-1524. Tome I, Années 1521-1522. Tome II, Années 1523-1524. Geneva: Droz.

Martineau-Génieys, Christine. 1974. Le thème de la mort dans la poésie française de 1450 à 1550. State doctoral thesis presented in Montpellier on 1974 March 02. Published in 1978, Paris: Éditions Honoré Champion; republished in 2009.

Martineau-Génieys, Christine. 1996. Études sur «L'Heptaméron» de Marguerite de Navarre. Colloque de Nice organisé par Christine MARTINEAU- GÉNIEYS 15-16 Février 1992. Publications de la Faculté des Lettres, Arts, et Sciences Humaines de Nice. Nouvelle série, $N^{\circ} 29$. Nice: Université Nice Sophia Antipolis.

Martineau-Génieys, Christine, Ed. 1997. Clément Marot et «L'adolescence clémentine». Actes des cinquièmes Journées d'études du XVIe siècle de l'Université de Nice-Sophia Antipolis, Nice, Association des Publications de la Faculté des Lettres de Nice.

Euvres de André Martineau. 1977. Paris: Éditions du Centre national de la Recherche scientifique, $879 \mathrm{pp}$.

Schwartz, Laurent. 1977. Notice biographique. In: (Euvres de André Martineau 1977:7-13). 
Schwartz, Laurent. 1997. Un mathématicien aux prises avec le siècle. Paris: Odile Jacob.

Publisher's Note Springer Nature remains neutral with regard to jurisdictional claims in published maps and institutional affiliations. 